\title{
About the supra-generic classification of the Marginelliform Gastropods: a morphological study
}

\author{
Franck Boyer \\ 4, impasse Pasquier, 30190 Garrigues Sainte Eulalie, France: e-mail: franck.boyer7@ orange.fr
}

\begin{abstract}
The supra-generic classification of the marginelliform gastropods is reevaluated on the ground of a critical review of the main general revision works dealing with the combined analysis of the conchological characters, of the external anatomy and of the radular morphology, and less systematically of the organization of the alimentary tract. The disparate nature of several groups is demonstrated, and it provides grounds for the description of three new supra-generic taxa: Marginellonidae fam. nov., Plesiocystiscinidae fam. nov. and Canalispirinae subfam. nov.
\end{abstract}

KEY WORDS

Marginellidae; Cystiscidae; Granulinidae; taxonomic classification; morphology; cladistics.

Received 26.08.2019; accepted 14.09.2019; published online 18.09.2019

\section{INTRODUCTION}

The integrative taxonomy of the marginelliform gastropods has found probably its first hearty demonstration in the precursory work of Coan (1965) who proposed a relatively innovative classification confronting the conchological data with some available elements concerning the external anatomy of the animals and the types of the radulae. Coan (1965) proposed to recognize three sub-families within a single family Marginellidae J. Fleming, 1828: Marginellinae J. Flerming, 1828 and Cystiscinae Stimpson, 1865 implicitely derived respectively from Marginellidae and from Cystiscidae Stimpson, 1865, as well as Marginelloninae subfam. nov., explicitely proposed for sheltering the two monospecific genera Marginellona Martens, 1904 and Afrivoluta Tomlin 1947.

In this formative period of the integrative taxonomy of the marginelliforms, the definition produced for each of these three sub-families remained eminently summary: the Marginellinae were de- fined as being composed of the "largest species", with a radular plate said to be "flat or curved with many cusps", whereas the Cystiscinae were defined as being composed of "very small species with characteristic white shells" and provided with " $a$ small and arched radular plate with fewer cusps", when the Marginelloninae were recorded as "relatively large species with radular plates bearing $\mathrm{nu}$ merous cusps".

The family Marginellidae did save his unifying status, whereas the family Cystiscidae went downgraded at the rank of sub-family within the Marginellidae. In his conclusion, Coan (1965) detailed the composition of these three sub-families in genera for the fauna of the Panamic Province ("West American species"), and he annexed a list of all the available genera, as well as their synonymy.

The anatomical study of Ponder (1970) about four marginelliform species from Indo-Pacific Province and its exploitation in the frame of a broader reflexion about the taxonomy of the neogastropods (Ponder, 1974), followed by a work 
of Fretter (1976) about the Panamic species Volvarina taeniolata Mörch, 1860 all together ushered a true comparative anatomy applied to the marginelliforms, lifted the documentary investigations to higher level of detail and thoroughness, and provided the framework of a radical reconstruction of the organization of the group. Ponder (1974) did conclude about an intermediary position of the Marginellidae (sensu lato) between the Volutidae and the Volutomitridae, while pointing out at the same time a greater proximity with the latter, based on the similarity of the columellar plaits and of several shared anatomic characters (one single ingestive gland, right diverticula of the renal organ approaching or penetrating the renal-genital duct, lateral radular teeth lacking in the Marginellidae versus faint or lacking in the Microvolutidae, as section of the Volutomitridae).

Directly inspired by these seminal works, Coovert (1986), continued by Coovert \& Coovert (1990), did enter into a methodic work of documentation about the marginelliforms from various aspects, which will play as pieces preparing their "Revision of the Supraspecific Classification of the Marginelliform Gastropods" published on 1995. Among the most prominent of these preparatory monographies: an essay on the genus Cystiscus Stimpson, 1865 (Coovert, 1986), another on the genus Afrivoluta (Coovert, 1987a), a compilation about the external anatomy of the marginelliforms (Coovert, 1987b), another compilation devoting to the conchological characters (Coovert, 1988), a third compilation about the general radulae (Coovert, 1989), followed by a focus on the radulae in the Volvarina/Prunum group (Coovert \& Coovert, 1990), displaying a good number of unpublished data.

Harasewych \& Kantor (1991) did extend the Ponder's method, applying it to the elusive species Marginellona gigas (Martens, 1904) from southeastern Asia. The authors confirm the belonging of Marginellona (and by extension: of the Marginelloninae) to the family Marginellidae, however with some consistant reserves. After to have remembered the initial attribution of M. gigas and of Afrivoluta pringle $i$ Tomlin, 1947 to the family Volutidae (in particular for the head shape and for the morphology of the columellar plaits), and the original features which led to their subsequent placement in the family Marginellidae (radular morphology , lacking of operculum, polished surface of the shell, vitreous suture), Harasewych \& Kantor (1991) report the convergent anatomic features which seem to support "the original assignation of this taxon ( $A$ 's $N$ : $\mathrm{M}$. gigas) to the family Marginellidae (presence of a buccal caecum, uniserial radula with broad rachidian "comblike" plate, wide aperture of the digestive gland, wide rectal gland and palleal oviduct with separated ingestive gland and seminal receptacle)", before to underline some significant divergency traits, especially the non-specialized alimentary system of M. gigas, with a strong Gland of Leiblein without terminal bulb as well as an important Valve of Leiblein, which presents "features of primitive neogastropods so far not-recorded in the Marginellidae". Furthermore, M. gigas was said to be "deprived of both a glandular duct bypassing the Valve of Leiblein and as well as a salivary gland, which are present in the documented Marginellidae, including in the single species of Cystiscinae studied (A's $N$ : for this feature) hitherto". According to Harasewych \& Kantor (1991), these particularities suggest that the group Marginelloninae may constitute "the most primitive of the Marginellidae subfamilies", that means more primitive than the Cystiscinae, considered itself by Coovert (1989) as a primitive group within the Marginellidae from the fact of the inclusion of a triserial radulate species.

Coovert \& Coovert (1995) published their supraspecific revision of the marginelliforms, splitting the group in two families Marginellidae and Cystiscidae, the latter being restored for the occasion. The Marginellidae received two subfamilies: Marginelloninae Coan, 1965 and Marginellinae Flerming, 1828, the Marginelloninae remaining composed of their two monospecific genera Marginellona and Afrivoluta, and the Marginellinae being distributed in three Tribes (Austroginellini, tr. nov., Prunini tr. nov. and Marginellini J. Fleming, 1828) constitued of many genera. Four sub-families were recognized in the Cystiscidae: Plesiocystiscinae subfam. nov., Cystiscinae, Persiculinae subfam. nov. and Granulininae subfam. nov. This organization was based on the comparison of relatively broaden compiled data concerning the shell morphology, the external anatomy of the animals (principally the structural shape of the head) and the morphology of the radulae, data completed for some species and some genera by the description of 
the radular odontophore and/or of the alimentary canal.

This organization in families and sub-families will be adopted as soon by the malaco-taxonomists and for the most it will remain undisputed up to 2008, with the revision of the genus Serrata Jousseaume, 1875 for New-Caledonia by Boyer (2008), who considers the Tribes organization proposed within the Marginellidae as a mainly eclectic construction and suggests the transfer of the genera Serrata and Hydroginella Laseron, 1957 from the Tribe Austroginellini G.A. Coovert et H.K. Coovert, 1995 to the Tribe Prunini G.A. Coovert et H.K. Coovert, 1995. Some new genera have been proposed also after the general revision of Coovert $\&$ Coovert (1995), but without changing of the architecture of the marginelliforms organization they proposed, in particular: three new genera in the Plesiocystiscinae G.A. Coovert \& H.K. Coovert, 1995 for the Caribbean Sea (Intelcystiscus Ortea et Espinosa, 2001, Inbiocystiscus Ortea et Espinosa, 2001 and Ticocystiscus Espinosa et Ortea, 2002), a genus Paolaura Smriglio et Mariottini, 2001 from the Indian Ocean in the Granulininae, a genus Demissa Boyer, 2015 from the Indo-Pacific Province in the Marginellidae (implicitely associated to the Prunini), the two genera Granulinopsis Boyer, 2017 from northeastern Atlantic and Granulinella Boyer, 2017 from New Caledonia in the Granulininae (the latter genus with reserve).

A thesis worked by Souza (2007) about " $a$ cladistic analysis of the family Marginellidae based on comparative morphology" and documenting good number of new anatomical dissections, did confirm "the distinction between Marginellidae and Cystiscidae", the latter being prudently considered as "placed in more basal position within the Muricoidea". The same data have been subject to a new study by Souza \& Simone (in press), in view to give way to stronger conclusions about the inner organization of the Marginellidae and the relations with the most closely related groups (L. Simone, pers. comm.).

A noticeable questioning of the Coovert \& Coovert's suprageneric taxonomy will come on 2017 with the publication of a revision of the granuliniforms by Boyer (2017), who proposes to remove the sub-family Granulininae from the family Cystiscidae and to place it in a new family Granulinidae, said to hold several original features and considered to be phyletically closer to the Marginellidae and Volutidae than to the Cystiscidae. The principal traits adopted by Boyer (2017a) as diagnosis of the new family are: first the external anatomy (animal head of the Type 2 in Coovert \& Coovert) and the pattern of the alimentary canal studied by Perez-Dionis et al. (2001) ("organ of Leiblein made of a small bag provided with a short duct rejoining the digestive tract after to have passed through the oesophageal nervous ring"), these two characters being considered as similar to the pattern found in the Marginellidae, versus the slit head pattern occurring in the sub-families Cystiscinae and Persiculinae (the Type 2 animal being however found also in the Plesiocystiscinae, but constituting a plesiomorphic character, possibly analogous and widespread among non-closely related species); secondly the uniserial rachiglossan radula with central plate wearing "dorsal tubers or cusps" and the sculpture patterns of the shell (granulous microsculpture and overlying macrosculpture), these two features showing as perfectly original among the marginelliform gastropods and allowing the taxonomic separation of the granulinids at the family rank towards the Marginellidae as well as the Cystiscidae. In his revision of the Granunidae of Masirah (Oman), Boyer (2018) attributes the family in erroneous terms as "Granulinidae Boyer, 2017", a whereas the correct attribution is naturally "Granulinidae Coovert et Coovert, 1995", at the benefit of the Article 36 of the Code of Zoological Nomenclature.

On the ground of available documents about general morphology, we propose to complete the reorganization of the marginelliform gastropods in creating two new families for the respective placement of the sub-families Marginelloninae and Plesiocystiscinae, and in creating also a new subfamily within the Cystiscidae for the placement of the genus Canalispira Jousseaume, 1875 and possible close relatives.

\section{RESULTS}

\section{Discussion of the proposed taxonomies}

\section{Harasewych \& Kantor, 1991}

Harasewych \& Kantor (1991: 37-38) are focusing their demonstration in a comparative table of 15 
anatomical features documented for Marginellona gigas, 9 other Marginellidae species and one Cystiscidae species (Granula sp., as Duliculum sp. in Ponder, 1970, both junior synonyms of Gibberula Swainson, 1840), but without any Volutidae neither any Volutomitridae in the outgroup, while the comments from their Discussion mostly centres on the affinities of Marginellona with these two families. The 15 tested features are dealing with external anatomy for three of them, with the alimentary canal for 9 of them, and with the reproductive system for the last three. While the attribution of Marginellona to the Marginellidae by Martens (1904) was defended on the ground of the radular morphology (modified rachiglossan, with exclusion of the laterals, comblike central plate with short, thin, subequal and very numerous cusps), of the lacking of an operculum, of the polished shell surface and of the vitreous suture, these features have not been considered in the comparative table of Harasewych \& Kantor (1991), no more than the occurrence of a "deep groove on the dorsal side of the Marginellona head" (Fig. 1), despite the fact that all these characters are discussed in different places of their article.

Among the 15 features tested in their table, several of them seem to work as poorly discriminant

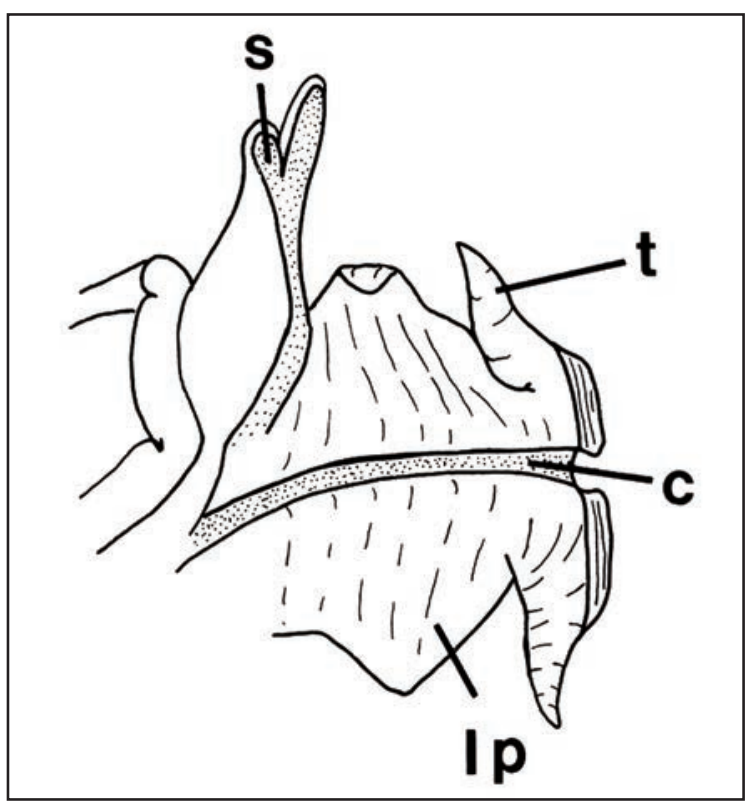

Figure 1. Cephalic morphology of Marginellona gigas (following Harasewych \& Kantor, 1995 fig. 15: $\mathrm{s}=$ siphon, $\mathrm{t}=$ tentacle, $\mathrm{c}==$ channel along mid-line of head, $\mathrm{lp}=$ lateral lappets. in the prevailing context: for instance Harasewych $\&$ Kantor (1991) admit that the fusion of the siphon with the head just seems to play as a frequent environmental adaptation to the burying move, found in fact in each of the three Marginellidae sub-families, and they moreover imply that such an adaptation does not hold any phyletical value. The extent and the position of the "siphon fusioning" are by the way not detailed, what is introducing a real ambiguity, from the fact that all the intergrading situations are in reality occurring, especially among some of the tested species (pers. obs.). The separative dorsal canal or gutter observed on the dorsal side is interpreted as a "tentacles fusion", what looks as a questionable wording and introduces a further ambiguity: the table reports the same feature in Granula (as Cystiscinae in Coan, 1965), without supporting this suggested homology in their comments, while the authors report the occurrence of a similar feature in at least three groups of Volutidae. At last, the authors underline that the third tested feature (the lateral lobes of the head) are totally original to Marginellona by reference to the rest of the Marginellidae group, but widely spread in the Volutidae. By themselves, these three features lead to regret that any Volutidae neither Volutomitridae were not used in the outgroup for this integrative test.

Other features tested by Harasewych \& Kantor (1991) seem unfitting in the context, like for instance the presence or absence of a radula, while the authors admit by themselves that "the loss of the radula is supposed to be of polyphyletic order". The presence or absence of aciniform salivary glands as well as the shape of the penis do not hold no more an evident discriminant value at the scale of the family or of the sub-family. By the way, the comparative table shows that the tested Marginellidae are disparate for these features, and most of the features and states tested in the table prove to have not discriminant value in the prevailing context.

Despite the fact that the authors do not notify the matter, we note that the sole Cystiscinae species tested here is sharing 9 of the 15 anatomical characters possessed by Marginellona gigas, while only two of the other tested Marginellidae present a better proximity (10/15 for Haloginella mustelina and 11/15 for Mesoginella pygmaea), one species of Marginellidae scoring about the 
same order than the Cystiscinae species, $7 / 13$ for Prunum martini (Petit de la Saussaye, 1853, and the 6 further Marginellidae scoring lower or very lower, from $0 / 5$ for Hyalina pallida (Linnaeus, 1758) to 5/12 for Prunum marginata (Born, 1778). By themselves, these results lead to question about the pertinence and the efficiency of the comparative method applied, like about the choice of the characters and of their modes, if not about the aim really pursued.

We observe moreover the introduction of noticeable biases, for instance concerning the apparent "absence" of such or such character, which might be in fact displaced, nanified or even badly searched: that is concretely the case for the supposed absence of a radula in Hyalina pallida, which has been finally proved to be a radulate species, like apparently all its genus (Boyer, 2015a), as well as for the genus Dentimargo Cossmann, 1899 reported as being non-radulate in the whole, whereas at least two Dentimargo species have been proved to be radulate (Boyer, 2005, 2017b). The cladistic practice is revealing herein some of its limits: the reliability of the observations worked, the discriminant value attributed to the characters, the ambiguity of the modes adopted for the definition of the characters states, and the real comparability of individual results.

\section{Coovert \& Coovert, 1995}

Coovert \& Coovert (1995) provide their analysis from a more important number of characters, dealing principally with the shell morphology, the external mophology of the animal (mostly the pattern of the head), the radular type, the type of odontophore and the anatomy of the alimentary canal. The study of the characters is more deepened than in Harasewych \& Kantor (1991) and it is also applied to a larger number of species. However, only the anatomical features are computed in a comparative table (Coovert \& Coovert, 1995: 54, Table 3), excluding the shell morphology features and often using excessively simplifying discriminatory modes, if not teleological ones. The integrative table proposed by Coovert \& Coovert (1995) only crosses in fact 14 characters, to be related to the 15 characters crossed by Harasewych \& Kantor (1991) in their own compative table.

The analysis of Coovert \& Coovert (1995) about the shell morphology does value some characters felt as "representative" of special evolutionary lineages, while shelving the variability factors which might trouble the demonstration, and avoiding, minimizing or relativising the interest either the importance of further conchological features. For instance the authors give a major place to the "partial

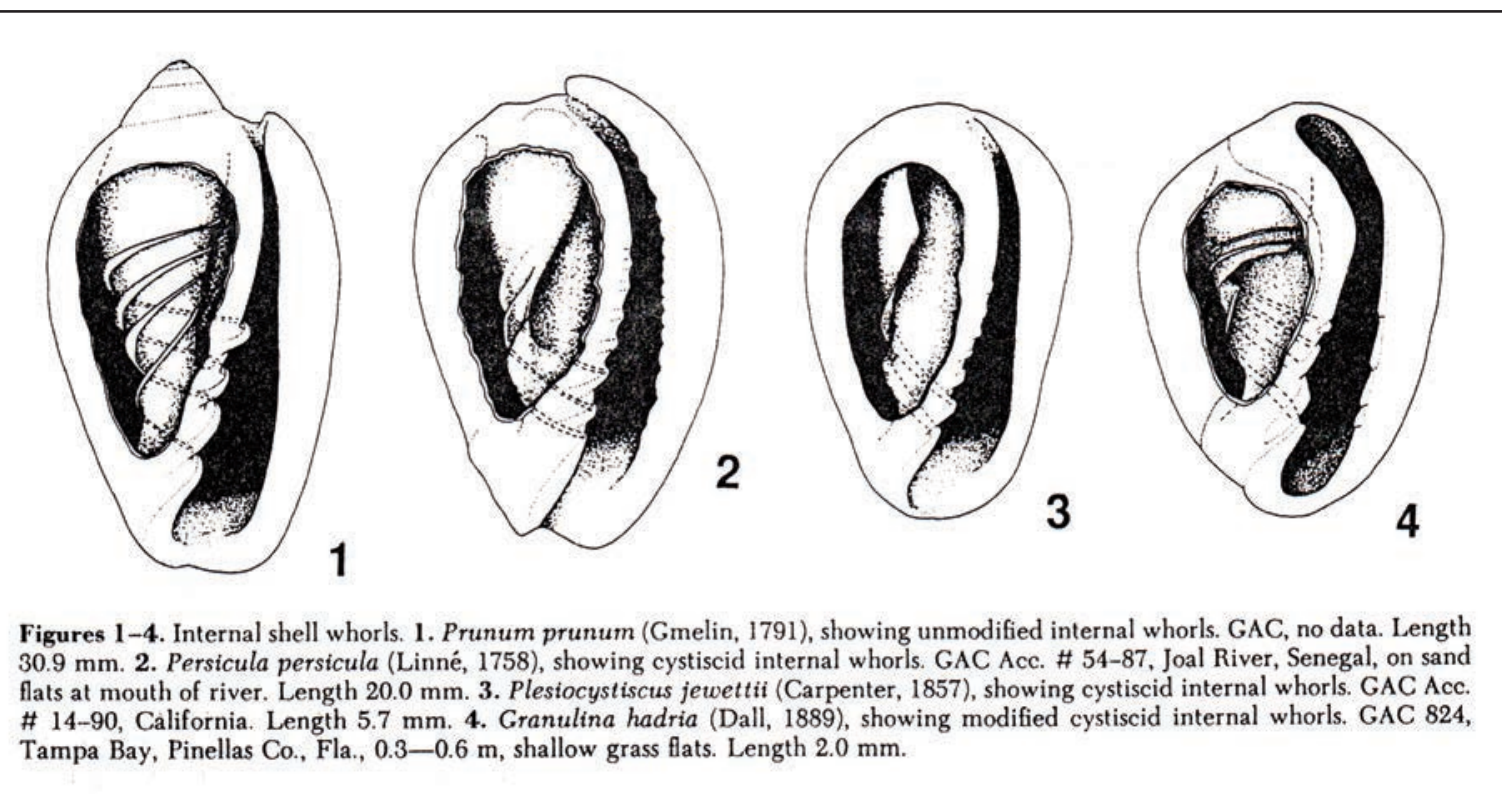

Figure 2. Internal architecture of the shells, following Coovert \& Coovert (1995, figs. 1-4). 
resorption of the internal whorls of the shell" (Fig. 2 ), what constitutes from their point of view a shared and unifying characters among the Cystiscidae. Boyer (2017a) demonstrated that this feature is noticeably variable within the granuliniforms, sometimes poorly marked or dubious in this group, and may result from a simple convergence linked to similar architectural constraints. In support to their demonstration, Coovert \& Coovert (1995: 49, figs. 1-4) present by the way a figure of Granulina hadria where the supposed "partial resorption of the internal whorls" is not at all evidenced (Fig. 2: fig. 4). Coovert \& Coovert (1995) make also an eclectic use of further conchological characters: they insist for instance on "the absence of a external labial varix" in the Cystiscidae, with the noticeable exceptions of the Granulininae where it is well-present and much marked, and of the genus Persicula where its presence should be irregular, whereas the external varix can be also factually represented in some Gibberula species, what is suggesting in the whole that this feature holds an eclectic status in the Cystyiscidae better than a dominant and characteristic status. The occurrence of labial teeth said to characterize some marginelliform genera is in fact most often facultative at the scale of some genera or at the level of several species groups, if not sporadic within such or such species. The shell macrosculptures are spotted as constituting a frequent or constant feature at the scale of several genera of Marginellidae (Austroginella Laseron, 1957, Glabella Swainson, 1840, etc.) but any diagnostic value is given to the micro and macro-sculptures found in the Granulininae, whereas the other groups attributed to the Cystiscidae are totally deprived of such features.

The study of the morphological types of the animal head in Coovert \& Coovert (1995) are subject to similar biases. For instance, the "slit or bilobate head" (Fig. 3) are recognized as constituting a shared character in the Cystiscidae groups considered as the "most evolved" ones (Cystiscinae and Persiculinae), but the similarity presented by the cephalic gutter in the Marginelloninae is not inquired in phyletic terms, despite the fact that Coovert \& Coovert (1995) did admit henceforth that this gutter is also occurring in Afrivoluta pringlei Tomlin, 1957 as it is in Marginellona gigas, what Coovert (1987a) did not remark previously.
The comparative analysis of the radular patterns (Fig. 4) is clearly flawed by a poorly argumented grouping trend, if not tarnished by implausibility. Coovert \& Coovert (1995) consider for instance that the "comblike radula with many cusps" of the Marginelloninae constitutes a plesiomorphic stage of the "comblike radula with fewer cusps" found in several Marginellinae groups, and from this statement they infer that the Marginellinae would be derivated from the Marginelloninae. This supposed filiation is just resting in fact on the intuition and on an apparent "common sense" against whom the taxonomical research is precisely supposed to defend itself: besides the fact that this character might be only analogous, it may more probably prove to come from the parallel evolution of very anciently separated modified rachiglossan lineages, or even it may play in the contrary (and more plausible) direction, with the numerous-cusps radula derivating from fewer-cusps radula. As result, the occurrence of this "comblike radula with many cusps" does not allow neither justify by itself to unify the Marginellinae and the Marginelloninae within a common family, and no more to speculate about the closeness of their kinship. In the same vein, the similarity alleged between the arched radula of the Granulininae and that of the Cystiscinae and Persiculinae Coovert \& Coovert (1995) seems to be quite unsubstantial: besides the fact that the analogy explanation remains once more possible, it must be observed that the radula of the Granulininae presents a deep originality in the details, especially concerning the "dorsal tubers or cusps" of the plates (Boyer, 2017a), any equivalent being known among the other groups of the marginelliform gastropods.

At last, the Plesiocystiscinae are considered as a "primitive" group of cystiscids which would have conserved a triserial radula, while the Cystiscinae brother-groups would loose the laterals, but would save the central tooth in heritage. In fact the shape of the central tooth in Plesiocystiscus Coovert et Coovert, 1995 differs noticeably from the uniseral plates found in Cystiscus, Gibberula and Persicula, from a sculpture with uneven reliefs not necessarily homologous with the Cystiscinae pattern, but finally more comparable to the pattern found in the Granulininae, where the sculpture of "dorsal tubers or cusps" is however more marked and well-different from an architectural point of view (Boyer, 2017a). 


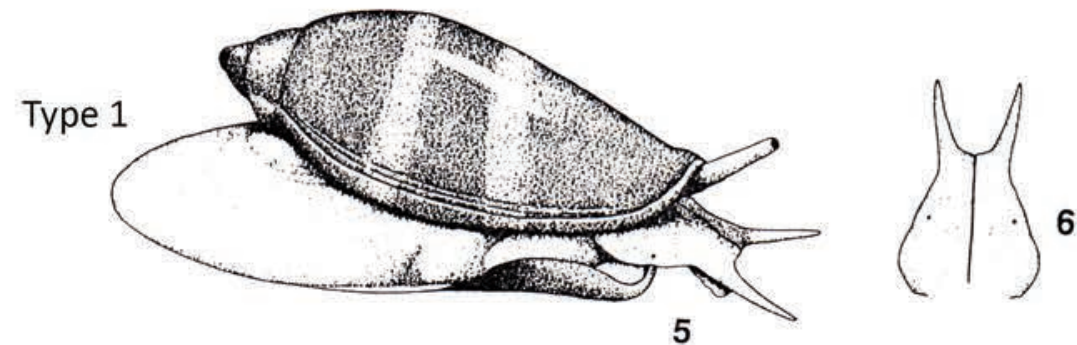

5

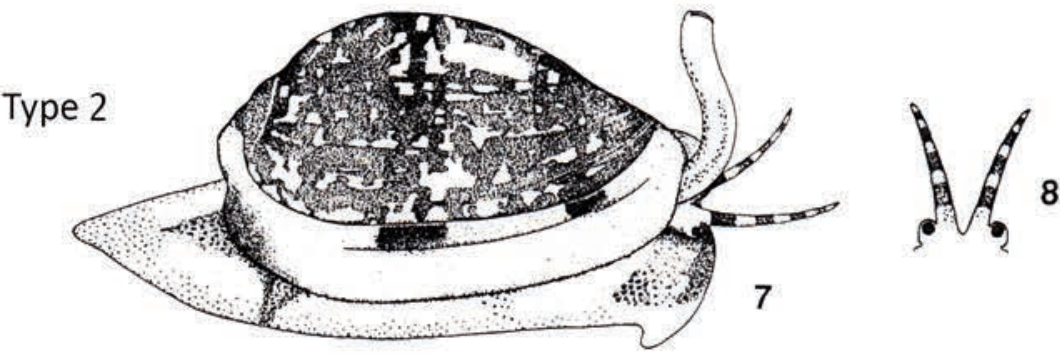

Type 3

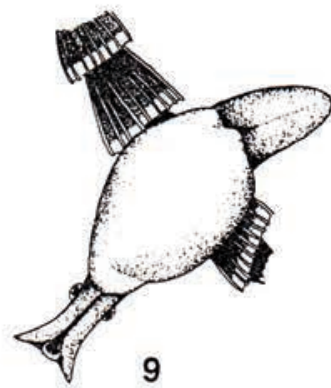

Type 4

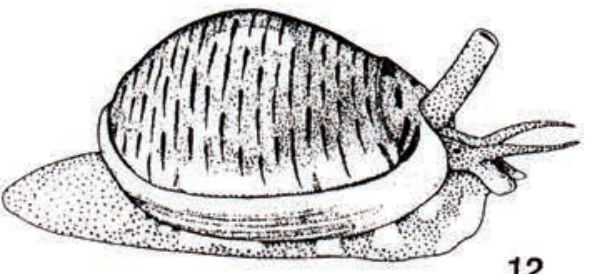

10

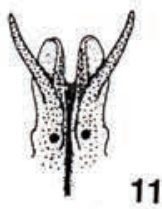

Figures 5-8. Marginellid external anatomy. 5, 6. Afrivoluta pringlei Tomlin, 1947, example of Type 1 animal. After Liltved (1985) plus pers. obs. of photos (ex. W. R. Liltved). Off Danger Point, western Cape Province, at $246 \mathrm{~m}$. Ca. X 0.65. 5. Animal viewed from right side. 6. Dorsal view of head. 7, 8. Prunum aff. aletes Roth, 1978, example of Type 2 animal. GAC 1518 , small island just off Tamarindo Beach, S. of Tamarindo Diria Hotel, Guanacaste Province, Costa Rica, under rocks, low tide. Shell length $19.4 \mathrm{~mm}$. 7. Animal viewed from right side. 8. Dorsal view of head. Figures 9-12. Cystiscid external anatomy. 9, 10. Cystiscus minutissimus (Tenison-Woods, 1876), example of Type 3 animal. After Murray (1970) and Coleman (1975). 9. Animal viewed from above. Ca. 9.0 X. 10. Dorsal view of head. Ca.18 X. 11, 12. Persicula interruptolineata (Megerle von Mühlfeld, 1816), example of Type 4 animal. GAC 1581, N. end of Playa La Galera, Isla de Margarita, Venezuela, NE side of bay, hand-dredged on sandy mud with small patches of Turtle Grass. Length $14.7 \mathrm{~mm}$. 11. Dorsal view of head. 12. Animal viewed from right side.

Figure 3. Types of the external anatomy (head), following Coovert \& Coovert (1995, figs. 5-12). 


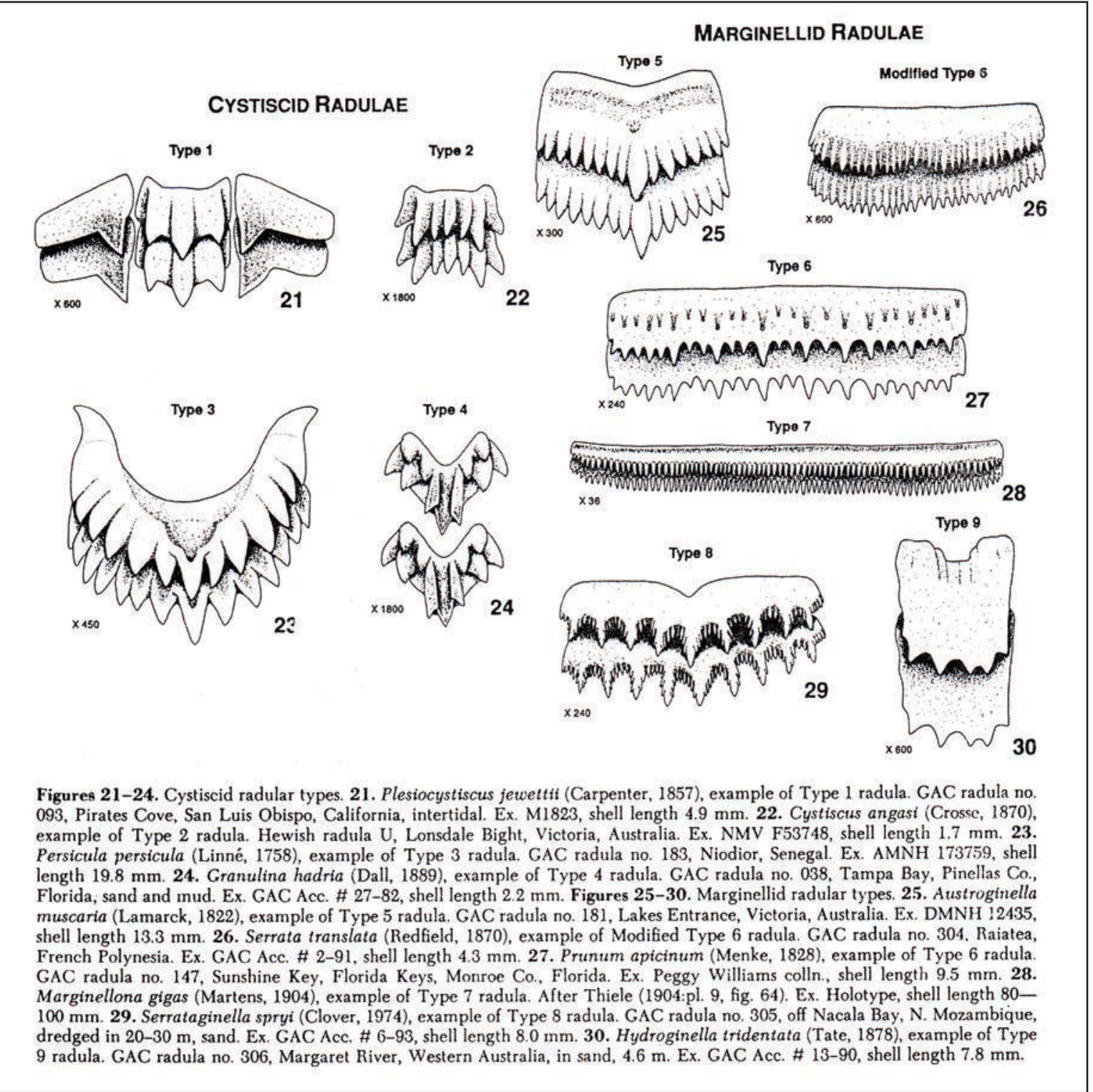

Figure 4. Types of the external anatomy (head), following Coovert \& Coovert (1995, figs. 5-12).

The analyse of the odontophore allows Coovert \& Coovert (1995) to shed a new light from original observations, this character being neglected until then in the study of the marginelliforms. The authors recognize two principal states in the odontophore of the marginelliforms: the occurrence of two separated plates versus the occurrence of two plates fusioned at the tip or fusioned in two points, the first state seeming to be general in the Cystiscinae and the second state seeming to be general in the Marginellinae, the absence of an odontophore being naturally acted in the non-radulate species or supposed to be. The data brought to light as well as the demonstration are convincing by themselves, but the number of species studied for this character remain extremely narrow: in fact Coovert \& Coovert (1995) did study directly the odontophore of only two species in the Cystiscinae (both attributable to Persiculinae) and of five species in Marginellinae (all attributable to the Volvarina/Prunum complex). For the rest, Coovert \& Coovert (1995) are dealing about faintly supported undirect sources for a very limited number of species (Ponder, 1970; Fretter, 1976; Ponder \& Taylor, 1992). In the whole, 
Coovert \& Coovert (1995) can refer to pieces of information (from direct observation and full-drawing down to short allusion) just for few species belonging to three genera or super-genera: Persicula/Gibberula, Volvarina/Prunum and Austroginella, out of various other Marginellidae genera holding "comblike radulae" (Marginellona/Afrivoluta, Cryptospira Hinds, 1844, Serrata, etc.) or strongly modified radulae (Hydroginella, Demissa, etc.), and also out of the majority of the genera placed by them in the Cystiscidae (Cystiscus/Crithe, Granulina, Plesiocystiscus). From this fact, the generalization supported by Coovert \& Coovert (1995) at the scale of their two proposed families Marginellidae and Cystiscidae looks as poorly argumented and quite hazardous.

The synthetic analysis of the anatomical characters looks as unbalanced from several points of view, particularly about the panel of tested species, constituted of three Cystiscidae (in fact only Persiculinae and not any Cystiscinae, Plesiocystiscinae or Granulininae) and of twenty-one Marginellidae (including Marginellona gigas, but out of numerous "atypical" genera such as Closia Gray, 1857, Cryptospira, Demissa, Hydroginella or Serrata). This lesser documentation of the Cystiscidae (sensu lato) results probably from anthropic biases: the lesser sampling of small-sized groups and their more difficult observation in vivo like on dissection duty both lead to a lesser recognizing of the taxonomic diversity and of morphologic disparity at work. Even if understandable by itself, the diversity bias introduced in the comparative Table is however important and it seems to be evident that the relative homogeneity suggested in the Cystiscidae would be certainly much lower (like prevailing in the 21 tested Marginellidae) if the groups Cystiscinae, Plesiocystiscinae and Granulininae would be integrated in the comparison.

The choices made about the testable characters and their modes calibration introduce also major biases, inducing for instance more important synapomorphies between Marginellona and the other Marginellidae than with the panel of tested Cystiscidae (in fact only Persiculinae), this from a deeply artificial manner.

As representative examples:

Character 1 (Buccal pouch) is splitted in the two modes "absent" versus "present", but the absence if buccal pouch does not present necessarily an homologous feature: we observe incidentally that the buccal pouch is reported as "absent" in the three radulate Persiculinae as well as in the seven nonradulate (or supposed to be) Marginellidae, what is giving account of two deeply different states and amount $\mathrm{s}$ to proceed to an eclectic classification.

Character 2 (Neogastropods radular sac) is also splitted in the "absent" versus "present" modes, but it introduces a double ambiguity: from one hand we do not understand if "absent" means "absence of any radular sac" or if it means "radular sac different from the Neogastropods sac pattern", what should refer to very constrasted solutions depending of the kind of radular sac implied; on the other hand, the Cystiscidae as well as the Marginellidae being Neogastropods, so how to define any "Neogastropods radular sac" which would be occurring in some marginelliform groups (or Neogastropods ones) but not in other ones ?

Character 3 (General radular type) is splitted in the three modes "cystiscid", "marginellid" or "absent": first such discrimination is perfectly tautologic (Cystiscidae having "cystiscid radulae" and Marginellids having "marginellids radulae"); secondly the "absence of the radula" does not constitute a feature from the same biologic and taxonomic nature, as representing a secondary or regressive stage, that means a subcategory playing equally within both families and not a valid category by its own; at last, the absence of a radula can come from various processes and to unit this state as a distinct category or mode is deprived of any signification. Same kind of remarks could be tackled for Character 4 (Specific radular type).

Character 6 (Siphon) is splitted in the two modes "attached left of head" versus "fused to head". Only Marginellona gigas and Prunum marginatum (Born, 1778) would share the second mode (siphon fused to head) while all the other Marginellidae as well as the three tested Persiculinae would share the first mode (siphon attached left of head). This definition is ambiguous because "fused" is by itself a kind of "attachment", and overall because very numerous species are observed at the live state as well as under dissection (pers. obs.) as displaying various attachment intergrades. Harasewych \& Kantor (1991) did observe abroad that the (partial) fusion of the siphon is essentially 
correlated to burrowing habits, and that such a "plastic" feature is poorly or not significant in the phyletic field.

Character 9 (Gland of Leiblein) is splitted in three modes: 1) "small, narrow gland, no terminal bulb"; 2) "large, sacculate gland, no terminal bulb"; 3) "with terminal bulb and long convoluted $d u c t$ ". The two first modes are questioning, by the fact that their differences seems to be very subtile and possibly not really discriminating. In fact the mode 1 concerns exclusively the three Persiculinae and the mode 2 concerns only Marginellona gigas, while mode 3 is uniting all the other tested Marginellidae. Such a subtile distingo operated between the modes 1 and 2 (better than to consider that they are variant stages in the same kind of gland) equal to create an artificial caesura for the sake of the cause: the Marginelloninae must have nothing to deal with the Cystiscidae and much to do with the Marginellidae.

We observe moreover that the absence of the Character "external anatomy/shape of the head" in the Comparative Table of the anatomic characters is not justified by Coovert \& Coovert (1995), and that it introduces another important bias, together because it masks a deep heterogeneity within the Cystiscidae (Type 2 animal sensu Coovert, 1987b in the Plesiocystiscinae and the Granulininae, Type 3 in the Cystiscinae, and Type 4 in the Persiculinae), but also because it is affecting the comparative analysis for Marginellona gigas, whose cephalic gutter suggests possible affinities with the slit head occurring in the Cystiscinae and the Persiculinae, and does not have homologues in the other Marginellidae which all have a Type 2 head.

If we put aside the first 4 Characters of the synthetic Table for the reasons presented hereabove and if we take in account the remark expressed about the Character 9, the Cystiscinae (= Persiculinae) just hold one original character among the 10 other integrated characters : the possession of an odontophore constituted by two separated plates (character non-tested in Marginellona). For the 9 other considered characters (from 6 to 14), at least one of the modes retained by Coovert \& Coovert (1995) is shared between the Cystiscidae (= Persiculinae) and the Marginellidae. More generally, we can consider that the Comparative Table of Coovert \& Coovert (1995) for the anatomical characters just demonstrate the separation between the Cystiscidae and the Marginellidae in a partial and not robust manner. By contrast, this Comparative Table should tell us about the position of Marginellona gigas, here incorporated in the Marginellidae but sharing an exclusive feature with two of the three Persiculinae (presence of the Valve of Leiblein) and apparently another exclusive feature with the three Persiculinae (Gland of Leiblein without a terminal bulb). If we consider the whole documented characters, the three Persiculinae do share no less features with Marginellona gigas than a good number of the tested Marginellidae species (in fact than the majority of them). If we agree with the equivalence of the modes 0 and 1 in the Character 9 (= Gland of Leiblein without terminal bulb) and if we restrict to the Coovert \& Coovert's accounting, the Persiculinae only share 4 to 5 of the 13 features attributed to Marginellona gigas, but 11 of the 20 other Marginellidae are in the same case.

\section{Souza, 2007}

Souza (2007) is focusing is thesis work on the Marginellidae in testing 22 species within an integrative Table of 93 characters, in the intention to refine the previous cladistic works, especially the supra-specific revision of Coovert \& Coovert (1995). Beside 18 species of Marginellidae (including Marginellona gigas newly dissected on two specimens), Souza (2007) propose an interesting outgroup of 4 species, including a Volutidae, Adelomelon brasilianus (Lamarck, 1811), and a Persiculinae, "Persicula" sagittata (Hinds, 1844). Among the 93 tested characters, 12 conchological characters are associated to 81 anatomical characters. Beside other valuable results, we note the study of the odontophore performed in Marginellona

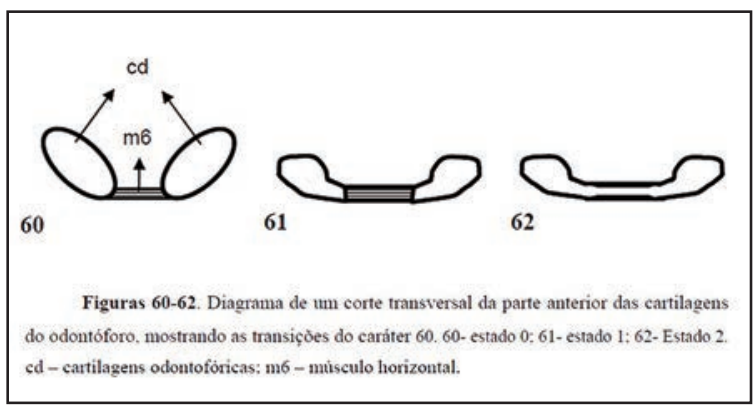

Figure 5. Synthetic patterns of odontophores (in cut), following Souza (2007, figs. 60-62). 
gigas: this odontophore proves to be composed of two separated plates, like it was observed in the Persiculinae, but in a special condition of attachment of the horizontal muscle, named as "model m6 modified" (Fig. 5: fig. 61) and differing from the usual model m6 "found generally in the Caenogastropoda". This special odontophore model might be considered as "transitional" towards the fusioned model found in the other Marginellidae. Souza (2007) reports that the odontophore found in Marginellona gigas is "very similar" to the one found in the Volutidae Adelomelon brasilianus.

We note also the observation made by Souza (2007) about the similarity presented by the "comblike radula with numerous cusps" found in Marginellona (83-85 cusps) and the "comblike radula with lesser cusps" found in other Marginellidae groups (Volvarina/Prunum, etc). Souza (2007) gives the average number of 45 cusps for the tested Marginellidae species, but in reality the average number is much lower in the documented Prunini species (Coovert \& Coovert, 1990; pers. obs.). Despite this point, the topographic test applied by Souza (2007) leads to the conclusion that the "comblike radula features" came out independently in the Marginelloninae and in the Prunini, and does not seem to play as a derived character.

In conclusion, Souza (2007) confirms however the Marginellidae (including Marginellona gigas) as constituting a monophyletic group supported by 17 synapomorphies, the Cystiscidae being considered as a more primitive group (more "basal" cladistic position) in the group Muricoidea.

Despite the fact that this kind of result is much conditioned by the methodologic and sampling choices initially operated, we can consider that 17 synapomorphies among a total of 93 tested characters constitute a rather modest and poorly conclusive score. Souza (2007) does not conclude nothing specifically bout the placement of Marginellona gigas, despite the heavy average divergence of its characters from the characters tested in the other Marginellidae. The synthetic Table of Souza (2007) let us see Marginellona gigas as equidistant between Adelomelon brasilianus, "Persicula" sagittata and the group constituted by the 17 other Marginellidae species.

\section{Boyer, 2017a}

In his revision of the granuliniforms, Boyer (2017a) does not bring new documentation, he is testing and commenting just a limited number of characters, he does not present any synthetic Comparative Table and he is just playing in fact a deductive approach on the ground of some data previously displayed in the literature. His proposition about the autonomization of the granuliniforms at the family level is principally resting on three general antinomies with the other Cystiscidae groups (internal shell whorls poorly or not resorbed; presence of micro and macro shell sculptures; organ of Leiblein with duct bypassing the oesophagic ring), one special antinomy with the Plesiocystiscinae (uniserial radula), two special antinomies with the Cystiscinae and the Persiculinae (non-slitted Type 2 head; embossed dorsal tubers or cusps on the radular plate) and two antinomies with the Marginellidae considered in their whole (shell micro-sculptures; narrow and arched radula with embossed tubers on the radular plate). For lack of available documentation about the odontophore at that time, this feature was not tested.

\section{Proposition of the creation of two new fami- lies and of one new subfamily}

We propose to reevaluate the position of the Marginelloninae and of the Plesiocystiscinae in the way initiated by Boyer (2017a), identifying the original features recognizable for these two groups and their taxonomic compatibility with other groups of the marginelliform gastropods. The eclectic composition observed in the Cystiscidae leads to reevaluate in particular the position of the genus Canalispira among them.

\section{MARGINELLONIDAE fam. nov.}

DESCRIPTION. Shell morphology: the type of the columellar pleats and the consistency of the surface lacquer in the Marginelloninae look as closer to those found in some Volutidae and Volutomitridae (Harasewych \& Kantor, 1991) better than to the models found in the Marginellidae or in the Cystiscidae, in which the porcellanous shell seems to have a different composition (pers. obs.).

External anatomy of the animal (shape of the head): the dorsal cephalic gutter has no equivalent in the Marginellidae, and it is not necessarily ho- 
mologous to the full-separation of the head in two distincts lobes as found in the Cystiscinae and Persiculinae (Harasewych \& Kantor, 1991; Souza, 2007). The lateral dewlaps are comparable to similar structures found in several groups of Volutidae; this character is clearly not homologous with the rather spread position of the posterior head observed in some Persiculinae or in the Olividae (pers. obs.).

Radula: the uniserial radula with wide central cusps bearing very numerous cusps, looks as similar to the basic model represented in Prunini and related groups (the genus Serrata, some Hydroginella, etc), but it does not seem to be a shared character or even to play as an "ancestral model" for them. The "primitive" state alleged for this radula bearing very numerous cusps does only rest itself on the prejudice attributing a great seniority to the Marginelloninae from the fact of their very limited diversity in the Recent together with their very patchy distribution are both connoting a relictual status, and on some anatomical features sometimes considered as archaic, however not factually in a different way that various archaic features retained in all the organisms, beside recently derived ones.

Odontophore: constituted of two separated plates, like in the pattern documented for the Persiculinae and antithetical with the pattern of "fusioned plates" documented for the Volvarina/Prunum group (Souza, 2007). The inter-plates muscular attachment shows to be of a particular type, possibly "transitional" between the "free state" and the "fusioned state", and the homology with the pattern found in the Persiculinae is not proved. For this character, Marginellona presents apparently a special affinity with some Volutide (Souza, 2007).

Alimentary canal: the presence of a nonthrough Valve of Leiblein conciliates Marginellona with the two Persicula proved to hold the same pattern, and it differentiates it from all the other Marginellidae, as well as from the sole Gibberula documented in this field (Harasewych \& Kantor, 1991; Coovert \& Coovert, 1995). If this character contributes to distinguish Marginellona from the other Marginellidae, it does not allow to confer a particular proximity with the Cystiscidae or with part of them, the ontogeny, the anatomy and the conservation of this organ presenting very hetero- geneous situations within the neogastropods (Kantor \& Fedosov, 2009). The absence of accessory salivary gland in Marginellona constitutes a less ambivalent datum, in so far as, if this gland is present in the three documented Persiculinae, it seems to be present in only the half-part of the Marginellidae species documented in this field by Coovert $\&$ Coovert (remarkably in all the tested Austroginelini).

REMARKS. Taxonomic placement: in the whole, the Marginelloninae show to be in higher proximity with the Volutidae and the Volutomitridae, specially concerning the shell morphology, the shape of the head and the odontophore pattern, even if for these two latter characters more or less important affinities are suggested with the Cystiscinae and the Persiculinae. The shape of their radula suggests that the Marginelloninae might have a more or less close relationship with the Prunini and related groups, but it does not state necessarily a direct filiation : the type of "comblike radula" might be inherited from a more or less undirect common ancestor, or even to play as a alternative evolutionary occurrence in parallel lineages of uniseriate rachiglossan gastropods. The presence of a Valve of Leiblein differentiates clearly the Marginelloninae from the other Marginellidae, but if it is shared apparently with all the Persiculinae, these two characters look as too much heterogeneous for a valuable statement about a possible close relationship. In the whole, the Marginelloninae do not suggest more affinities with the Marginellidae than with the Cystiscidae, and they seem to range in fact rather far from them. In anyway, the belonging of the Marginelloninae to the family Marginellidae looks as poorly convincing, and to consider them as possible subfamily of the Volutidae or of the Volutomitridae would play itself as a poorly supported taxonomical solution in the present state. In the precise case, the ambivalence of the established affinities leads better to state in favour of an original combination of characters deserving the attribution of an autonomous status to Marginelloninae group, better than in favour of an artificial attachment which plays overall as a negation of the morphological and anatomical disparities at work. In the state of the documentation, we consider the group of the Marginelloninae as presenting the conditions for a tentative attribution to a new family Marginellonidae within the Superfamily Muricoidea Rafinesque, 1815. 


\section{PLESIOCYSTISCINIDAE fam. nov.}

DESCRIPTION. Shell morphology: the resorption of the internal whorls, the absence of external labial varix and the absence of the siphonal notch observed in the Plesiocystiscinae are shared with the Cystiscinae, but these two latter features are not shared with the Persiculinae, which holds a more or less marked siphonal notch, and a more or less thickened external varix in several groups, and in the whole flatter and less lamelliform columellar plaits. On the other side, the total absence of external labial varix in some groups of Persiculinae (Gibberula philippii group, etc.) does not seem to be homologous with the absence of external varix in the Plesiocystiscinae and in the Cystiscinae (pers. obs.).

External anatomy (shape of the head): the Type 2 head (Fig. 6: non-bifurcated headwith extended tentacles and siphon) differs deeply from the Type 3 (bilobed headwithout tentacles neither visible siphon) and from the Type 4 (bilobed head with more or less extended tentacles ans siphon) respectively found in the Cystiscinae and in the Persiculinae, and it is not necessarily homologous with the Type 2 found in the Granulinidae and the Marginellidae, this pattern of $\mathrm{V}$-shaped head with pointed tentacles and siphon being widely spread in the neogastropods, including in several families placed in the group Muricoidea.

Radula: the triserial radula of the Plesiocystiscinae has been interpreted as being an "ancestral state within the Cystiscidae" (Coovert \& Coovert, 1995), but nothing is materially testifying such a statement, even if the loss of the laterals does not constitute by itself a more complex or extraordinary process than the full loss of the radula in some Marginellidae lineages. The shape of the central plate in the Plesiocystiscinae seems to be morphologically less close to the uniserial plate of the Cystiscinae and Persiculinae than to the plate of the Granulinidae (nowadays considered as an autonomous family presenting more affinities with the Marginellidae and the Volutidae than with the Cystiscidae), any evident conclusion not seeming to play, due to the important plasticity of this organ in most of the considered groups (the disparity of the radular types at work in the Marginellidae plays by itself as a very demonstrative experience field).
Odontophore: unknown.

Alimentary canal: unknown.

REMARKs. Taxonomic placement: despite the lacking of data about their internal anatomy, the Plesiocystiscinae present by themselves an important originality compared to the other Cystiscidae groups among which they were placed until now: their shell morphology presents similarities with that of the Cystiscinae, but the radula of the Plesiocystiscinae cannot be stated as constituting the evolutionary stage immediately preceding the uniserial radula found in the Cystiscinae (or the other Cystiscidae as well), and overall the external anatomy of the Plesiocystiscinae is sufficiently divergent from that of the Cystiscinae for to invalidate their grouping within the same family. We consider that the Persiculinae are by far more divergent from the Plesiocystiscinae. Without totally reject of a possible "ancestral status" of the Plesiocystiscinae towards the Cystiscinae, or even towards the Persiculinae in a more remote perspective, the important evolutionary distance suggested towards these two groups through their external anatomy justifies by itself the integration of the Plesiocystiscinae within an new autonomous family Plesiocystiscidae, itself placed in the Superfamily Muricoidea.

The distribution of the Plesiocystiscinae is known to range along the Panamic Province and on both sides of the tropical Atlantic Ocean (being apparently much rarer on the eastern side), but the group seems to be much more elusive in the IndoPacific Province. Two species from New Caledonia have been however attributed to Plesiocystiscus by Boyer (2003), on the ground of the characters of the shell associated to a Type 2 animal (Fig. 7), but without a research of the radula. As most of the numerous Cystiscus species ranging in the Indo-Pacific waters were only studied on the ground of their shell, we can expect that a good number of these so-said "Cystiscus species" will prove to belong to Plesiocystiscus or to brother-genera.

\section{CANALISPIRINAE subfam. nov.}

In the course of this study, the Persiculinae were reported as constituting a specially heterogeneous group, by reference in particular to the various transitional forms occurring between Persicula and Gibberula, but also within the Gibberula themselves (Gibberula philippii group, etc.). Among the 


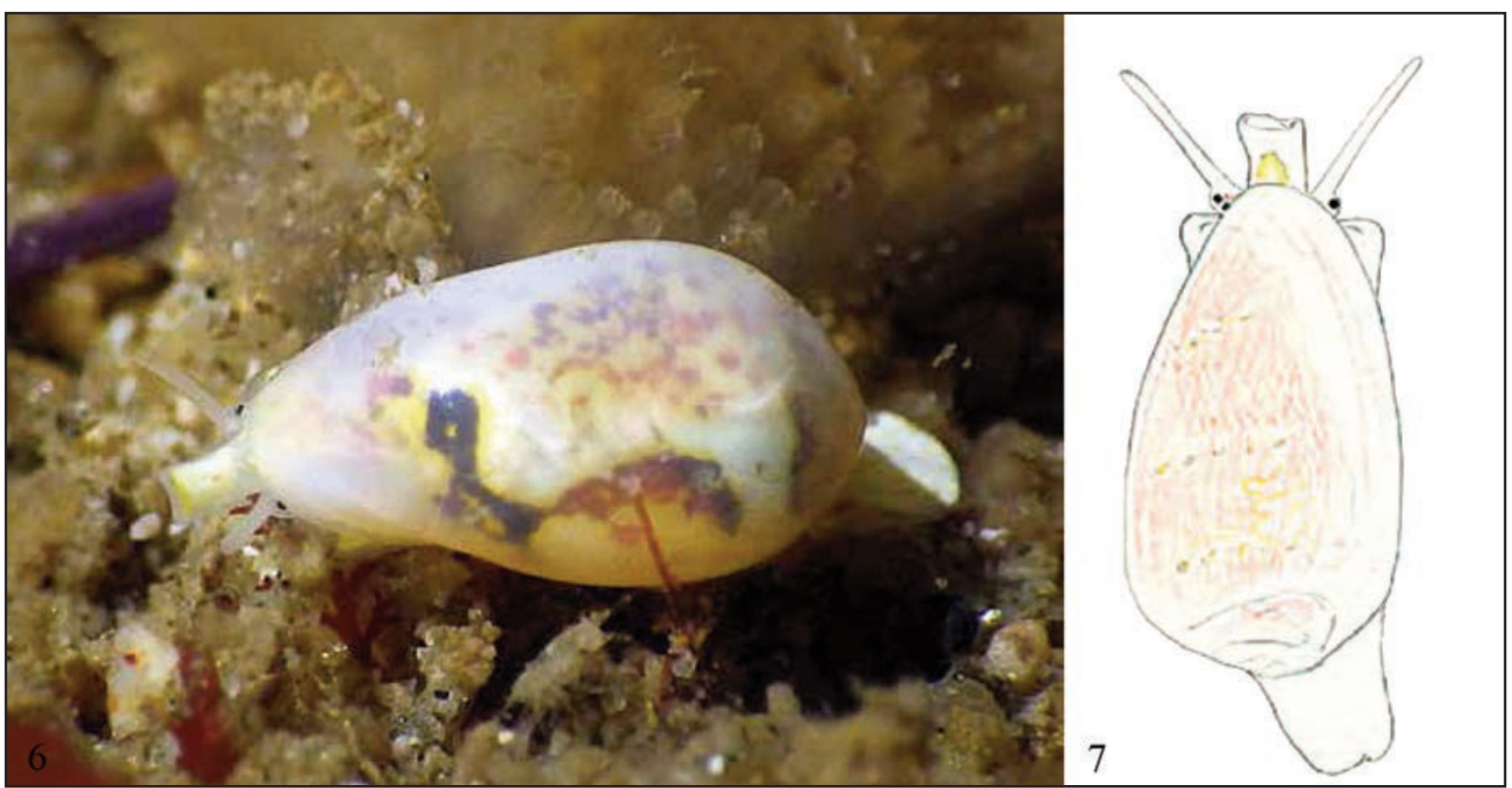

Figure 6. Plesiocystiscus jewetti (Carpenter, 1857), Cave Landing, Santa Barbara, Calif., by J. Goddard Figure 7. "Plesiocystiscus" bavayi Boyer, 2003, Touho, New Caledonia, in Boyer (2003, fig. 78).

Persiculinae, the genus Canalispira presents a set of specially composite characters, combinating a sharp and slender bilobed head, without appendices and no visible siphon (like occurring in the Cystiscinae), with a radula similar to that found in the Persiculinae (Type 3 sensu Coovert, 1987b) and a shell rather similar to that of this group, even for the columellar plaits, but however without siphonal notch (Coovert \& Coovert, 1995; McCleery \& Wakefield, 2007; pers. obs.).

In most of the Indo-West Pacific species, the Canalispira species present a more or less deeply canaliculated spire and undecored white shells, whereas in Caribbean similar species with the same general shell shape, same kind of external anatomy and same kind of radula are shown to be not canaliculated and to wear zic-zac shell decoration (McCleery \& Wakefield, 2007). The occurrence of several brother-genera may occur, but at least an intergrading situation was observed in the Maldives, with a full-white shelled species presenting a noncanaliculated spire (Boyer, 2018b).

The original combination of features in the external anatomy and in the shell morpology of Canalispira (Fig. 8: lectotype of the type-species Canalispira olivellaeformis Jousseaume, 1875) leads to propose to integrate this genus in a new au- tonomous subfamily Canalispirinae within the Cystiscidae, beside the subfamilies Cystiscinae and Persiculinae.

The species described from São Tomé as " $G i b$ berula" cucullata by Gofas \& Fernandes (1998) presents together a sharp and slender bilobed head deprived of tentacles, perfectly similar to the Canalispira pattern, but also a short but visible siphon and a shell belonging to the classic Gibberula-pattern, with an evident siphonal notch and prominent labial teeth. The possible replacement of this transitionallooking species will deserve to be studied by itself.

\section{CONCLUSIONS}

The new supra-generic organization proposed for the marginelliform gastropods consists to recognize five families in a group which must be considered in the present state as polyphyletic within Muricoidea, and to proceed to the creation of a new subfamily in the Cystiscidae, conserving for now the rest of the organization proposed previously by Coovert \& Coovert concerning the composition in subfamilies and tribes (with the replacement of Serrata and Hydroginella in the Prunini, as reported before). 


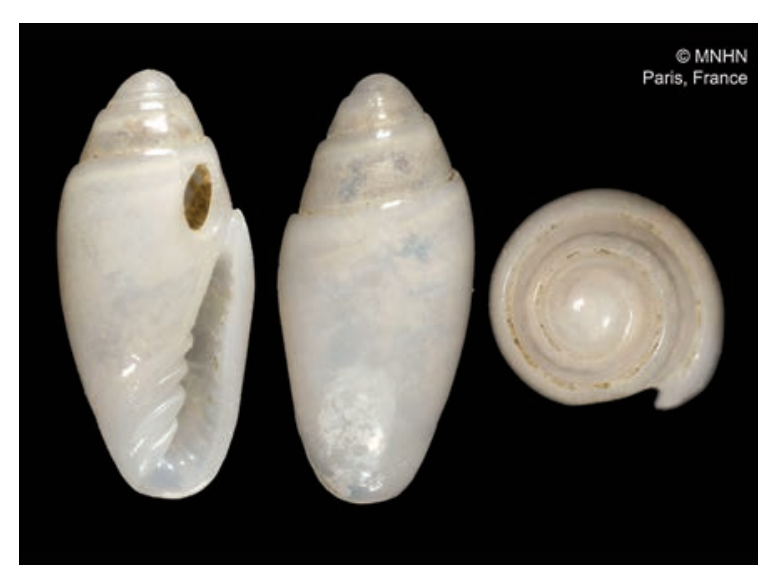

Figure 8. Canalispira olivellaeformis Jousseaume, 1875, lectotype MNHN, $4.1 \mathrm{~mm}$.

Familia MARGINELLIDAE Fleming, 1828 Subfamilia MARGINELLINAE Fleming, 1828 Tribe AUSTROGINELLINI Coovert et Coovert, 1995 Tribe PRUNINI Coovert et Coovert, 1995 Tribe MARGINELLINI Fleming, 1828

Familia GRANULINIDAE Coovert et Coovert, 1995

Subfamilia GRANULININAE Coovert et Coovert, 1995

Familia MARGINELLONIDAE fam. nov. Subfamilia MARGINELLONINAE Coan, 1965

Family CYSTISCIDAE Stimpson, 1865

Subfamilia CYSTISCINAE Stimpson, 1865

Subfamilia PERSICULINAE Coovert et Coovert, 1995

Subfamilia CANALISPIRINAE subfam. nov.

Familia PLESIOCYSTISCIDAE fam. nov. Subfamilia PLESIOCYSTISCINAE Coovert et Coovert, 1995

The revision worked presently by Souza \& Simone (in press) will surely bring new useful morphological and taxonomical elements about the organization of the Marginellidae. A supra-specific revision of the marginelliforms based on molecular data is also at work by a research team managed by A. Fedosov in the Muséum national d'Histoire naturelle (Paris, France): their demonstrations and conclusions will be also highly useful to address.

\section{ACKNOWLEDGEMENTS}

I wish to acknowledge here Luiz Ricardo Simone (Museu de Zoologia, Universidade de São Paulo) and Alexander Fedosov (Severtzov Institute, Russian Academy of Sciences, Moscow) which both contributed to the clarification of my aims and to the rationalization of my method in this work. I must thank also Jeffrey Goddard (Marine Science Institute, University of California, Santa Barbara) for the photos of live specimens of Plesiocystiscus jewetti. As often, I am indebted to Alain Robin (Le MesnilSaint-Denis, France) for his help in the mounting of the iconography, and to Walter Renda (Amantea, Italy) for his indefectible support. The photographies of the types of Canalispira olivellaeformis were performed by Manuel Caballer in the frame of the E-Recolnat program (ANR-11-INBS-0004).

\section{REFERENCES}

Boyer F., 2003. The Cystiscidae (Caenogastropoda) from upper reef formations of New Caledonia. Iberus, 21: 241-272.

Boyer F., 2005. The discovery of a radula in a Dentimargo species and its taxonomic implications. Iberus, 23: 47-52.

Boyer F., 2008. The genus Serrata Jousseaume, 1875 (Caenogastropoda: Marginellidae) in New Caledonia. In: Héros V., Cowrie R. H. \& Bouchet P. (Eds.), Tropical Deep-Sea Benthos, 25. Mémoires du Muséum national d'Histoire naturelle, 196: 386-436.

Boyer F., 2015a. Révision des marginelles de Linné (Mollusques prosobranches: Marginellidae et Cystiscidae). Xenophora Taxonomy, 8: 33-55.

Boyer F., 2015b. Etude d'un nouveau genre de Marginellidae (Mollusca: Neogastropoda) de l'Indo-Pacifique. Xenophora Taxonomy, 9: 31-48.

Boyer F., 2017a. Révision de l'organisation supra-spécifique des gastéropodes granuliniformes. Xenophora Taxonomy, 16: 25-38.

Boyer F., 2017b. Révision des Marginellidae du récifal supérieur de l'île de Masirah (Oman). Xenophora Taxonomy, 17: 3-31.

Boyer F., 2018a. Révision des Granulinidae du récifal supérieur de l'île de Masirah. Xenophora Taxonomy, 20: 3-13.

Boyer F., 2018b. Révision des gastéropodes marginelliformes dans le récifal supérieur des Maldives. Xenophora Taxonomy, 21: 22-47.

Coan E., 1965. A Proposed Reclassification of the Family Marginellidae. The Veliger, 7: 184-194. 
Coovert G.A., 1986. Notes on the Genus Cystiscus and its Type Species. Marginella Marginalia, 1: 20-24.

Coovert G.A., 1987a. The genus Afrivoluta and a review of the type species Afrivoluta pringlei Tomlin, 1947. Marginella Marginalia, 2: 1-8.

Coovert G.A., 1987b. A literature review and summary of marginellid external anatomy. Marginella Marginalia, 3: 8-25.

Coovert G.A., 1988. Taxonomic characters in the family Marginellidae: conchological characters. Marginella Marginalia, 4: 43-47.

Coovert G.A., 1989. A literature review and summary of published marginellid radulae. Marginella Marginalia, 7: 1-37.

Coovert G.A. \& Coovert H.K., 1990. A study of marginellid radulae. Part I : type 6 radula, "Prunum / Volvarina" type. Marginella Marginalia, 8-9: 1-68.

Coovert G.A. \& Coovert H.K., 1995. Revision of the Supraspecific Classification of Marginelliform Gastropods. The Nautilus, 109: 43-110.

Espinosa J. \& Ortea J., 2002. Nuevas especies de marginelliformes de Cuba, Bahamas y el Mar Caribe de Costa Rica. Avicennia, 15: 101-128.

Fretter V., 1976. The anatomy and feeding of the volutacean prosobranch Volvarina taeniolata Mörch. Journal of Molluscan Studies, 42: 327-336.

Gofas S. \& Fernandes F., 1988. The Marginellidae of São Tomé, West Africa. Journal of Conchology, 33: 1-30.

Harasewych M.G. \& Kantor Y., 1991. Rediscovery of Marginellona gigas (Martens, 1904), with notes on the anatomy and systematic position of the subfamily Marginelloninae (Gastropoda: Marginellidae). Nemouria, 37: 1-19.

Kantor Y. \& A. Fedosov, 2009. Morphology and development of the valve of Leiblein: Possible evidence for paraphyly of the Neogastropoda. The Nautilus, 123: 73-82.

Marten E. von, 1904. Die beschalten Gastropoden der deutschen Tiefsee-Expedition 1898-1899. A systematisch-geofraphischer Teil. Wissenschaftliche Ergebnisse der deutschen Tiefsee-Expedition auf dem Dampfer "Valvidia", 7: 1-146 ; pls 1-4.
McCleery T. \& Wakefield A., 2007. A review of the enigmatic genus Canalispira Jousseaume, 1875 (Gastropoda, Cystiscidae) with the description of three new species from the western Atlantic. Novapex, 8: $1-10$.

Ortea J. \& Espinosa J., 2001. Intelcystiscus y Inbiocystiscus (Mollusca: Neogastropoda: Cystiscidae) dos nuevos géneros del Atlantico occidental tropical. Avicennia, 14: 107-114.

Ortea J. \& Espinosa J., 2016. La subfamilia Plesiocystiscinae G.A. Coovert \& H.K. Coovert, 1995 (Mollusca: Gastropoda) en La Guadeloupe, Antillas Menores. Revista de la Academia Canaria de Ciencias, 28: 65-78.

Perez-Dionis G., Ortea J., Moro L. \& J.J. Bacallado J.J., 2001. Anatomía básica de Granulina guancha (d'Orbigny, 1829) (Mollusca: Neogastropoda: Cystiscidae). Vieraea, 29: 125-130.

Ponder W.F., 1970. Some Aspects of the Morphology of Four Species of the Neogastropod Family Marginellidae with a Discussion on the Evolution of the Toxoglossan Poison Gland. Journal of the Malacological Society of Australia, 2: 55-81.

Ponder W.F., 1974. The Origin and Evolution of the Neogastropoda. Malacologia, 12: 295-338.

Ponder W.F. \& Taylor J.D., 1992. Predatory shell drilling by two species of Austroginella (Gastropoda: Marginellidae). Journal of Zoology, 228: 317-328.

Smriglio C. \& Mariottini P., 2001. Description of Paolaura gen. nov. and of three new species of Cystiscidae from the Indian Ocean. La Conchiglia, 33 (299): 11-17.

Souza P.J.S. Jr., 2007. Análise cladística da família Marginellidae (Mollusca, Gastropoda) baseada em morfologia comparada. Tese doutorale, Instituto de Biociências, Universidade de São Paulo. I-XI, 1128, figs. 1-115.

Souza P.J.S. Jr \& Simone L.R., in press. Cladistic analysis of the family Marginellidae (Mollusca, Gastropoda) based on phenotypic features. Zootaxa. 